\title{
Precipitation extremes during flooding in the Odra River Basin in May-June 2010
}

\author{
Wiwiana Szalińska, Irena Otop, Tamara Tokarczyk \\ Institute of Meteorology and Water Management, National Research Institute, Wrocław Branch, Parkowa Street 30, \\ 51-616 Wrocław, Poland, e-mail: wiwiana.szalinska@imgw.pl
}

\begin{abstract}
Flooding in East-Central Europe in May and June 2010 also affected the Odra River Basin. Unlike a typical summer flood scenario, in 2010 intensive precipitation was observed as early as May. Also, the location of the most intensive rainfall shifted to the catchments of the right bank tributaries of the Odra River. This paper presents the climatological assessment of the precipitation totals that caused two flood waves on the Odra River. The assessment was carried out with the use of selected indicators: monthly precipitation totals, daily precipitation totals, number of days exceeding given precipitation levels, number of days with precipitation of a given probability of exceedance and intensity, duration and accumulation of precipitation for a number of consecutive wet days. The reference values for climatological indicators were developed for the period 1966-2009. The values of the selected indicators were analyzed in terms of flood hazard in relation to the hazard gradation. The results show that the observed precipitation had the character of an extreme event with respect to its magnitude, duration and spatial extent. The catchments with recognized high levels of flood hazard were affected by the flood wave. The flood situation caused by the extreme precipitation was evaluated in the context of the largest floods in this region during recent decades.
\end{abstract}

Key words: extreme precipitation, flood, Odra River Basin

Submitted 19 November 2013, revised 2 February 2014, accepted 6 May 2014

\section{Introduction}

The Odra River is the second largest river in Poland. It forms an integral part of the Central European drainage network (Sen, Niedzielski 2010). It originates at the foothills of the Sudetes Mountains in the Czech Republic and flows northward through Polish territory into the Baltic Sea. The total length of the river is $854 \mathrm{~km}$, including both Polish and Czech sections. The maximum elevation of the Sudetes Mountains is 1602 meters above sea level. The region of Sudety Mountains are characterized with the highest after Carpathian Mountains annual precipitation totals in Poland. Simultaneously, the area is marked by a large precipitation variation due complex orography causing the increase in the amount of precipitation with the altitude and rain shadows. The rivers draining the Sudetes and its foreland are prone to serious flooding that may occur after extreme rainfall and snowmelt. Precipitation flooding in the Odra River Basin is usually associated with frontal low-pressure centres that reach Poland following track $\mathrm{Vb}$ in the Van Bebber classification. These centres produce prolonged and intensive precipitation in southern Poland (Wrona 2007). Apart from synoptic causes, morphological conditions of the Odra River Basin such as elevation, exposure, landform etc., also play an important role in the influence on flooding. A comparison of historical and current flood zones in Poland indicates that both now and in the past the areas of frequent and catastrophic precipitation-based floods have been located mainly in the Upper and Middle Odra River Basin (despite significant changes in the management of the basin). According to the Polish National Department of Safety and Crisis Manage- ment, the biggest risk of flooding is recognized for the are-as of five provinces of Lower Silesia. In the province of Lower Silesia the highest flood hazard come from the following rivers : Mała Panew, Nysa Kłodzka, Bystrzyca and Kaczawa. Besides the volume and the intensity of pre-

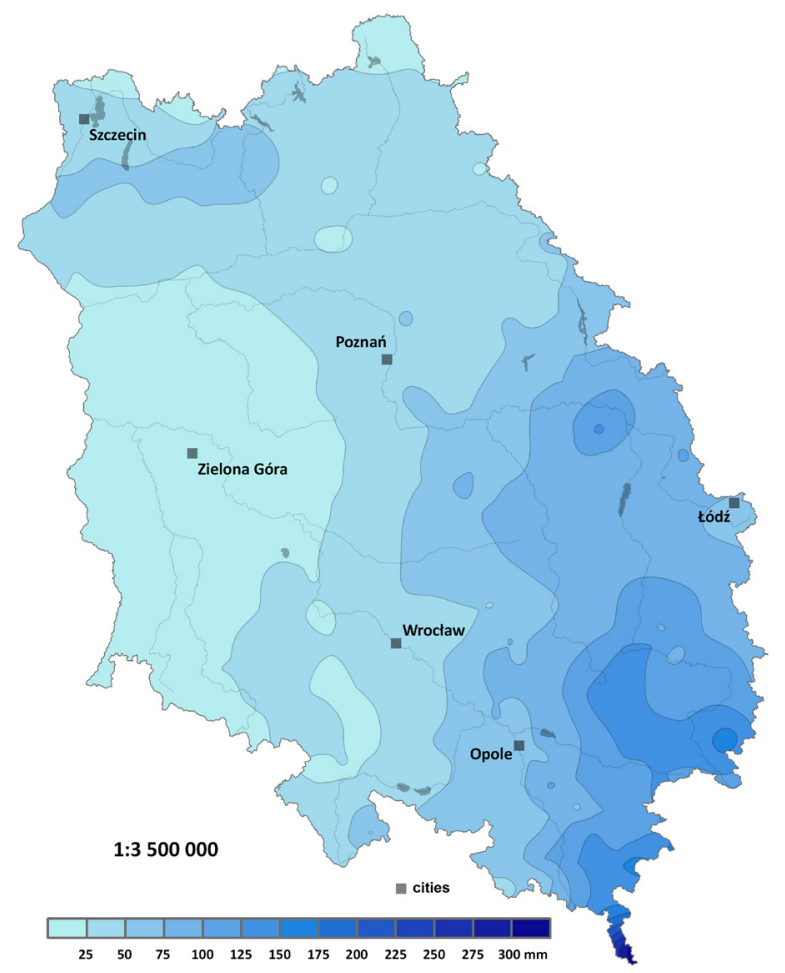

Fig. 1. Hydrographical condition of the Odra River Basin; source: own studies 
cipitation, another cause of summer flooding on the Odra is the order of outflows from particular catchments, and their role in the formation of a flood wave. Another negative factor is the complicated hydrographical condition of the Odra River Basin (Fig. 1). In many cases, the catchment area centres are located within large valleys surrounded by mountain ranges (Kłodzka Valley, Jeleniogórska Valley). In conjunction with converging tributaries, these conditions cause a rapid surface runoff (Dubicki et al. 2005)

These factors contributed to the recent severe precipitation floods on the Odra River in 1977, 1985, 1997, 2001 and 2002. Floods observed in the region usually occur during the summer season (July-August) and start in the headwaters area of the Odra River. Unlike this typical summer flood scenario, the 2010 flood took place in May and affected mostly the right bank tributaries of the Upper and Middle Odra River. At that time, exceptionally heavy rainfall was also observed in other regions of Eastern Central Europe, resulting in flooding on the Vistula, Tisza and Danube rivers (Bissolli et al. 2011).

The purpose of this paper is to investigate the statistical properties of precipitation extremes during the flood event in 2010 in the Odra River Basin. A good understanding of the statistical properties of precipitation patterns and their hydrological consequences is essential for flood prediction and control as well as for water management.

\section{Data and methods}

The study was based on the daily precipitation totals for May-June 2010 from 465 IMGW-PIB stations located in the Odra River Basin. Long-term daily data series, collected by 128 selected stations, constituted the basis for determining the threshold values of statistical indicators.

Identification of extreme precipitation events is an important element in the assessment of hydrological hazards and their potential effects. To identify extreme rainfall events, five indicators within the frame of hydrological hazard were selected (Table 1). An analysis of rainfall totals, frequency, duration and the percentage of high intensity precipitation was carried out. The selected indicators have proven to be good for the monitoring of precipitation extremes and changes in extreme precipitation (Klein Tank et al. 2009; Moberg, Jones 2005; Nicholls, Murray 1999).

The most commonly used method for the determination of extreme phenomena can be divided into two classes: a priori indicators related to the thresholds adopted on the basis of literature, and statistical indicators. A priori indicators allow for a preliminary assessment of rainfall hazard and are particularly useful in forecasting.

The basic statistical indicator characterized by extreme precipitation events is that of maximum daily rainfall. The highest values of this indicator are most often associated with short-term heavy rainfall.

The threshold values for the identification of extreme precipitation were defined on the basis of the analysis of long-term data and adopted as the empirical exceedance probabilities of $10 \%, 5 \%$ and $1 \%$. The probability distribution of precipitation was appointed to the sum of $\geq 0.1 \mathrm{~mm}$. On the basis of the accepted threshold values, rainfall was defined as heavy, very heavy and extreme, respectively. Such approved thresholds reflect the variability of precipitation in different periods of a year, and also significant differences in the relief and altitude of the Odra River Basin which affect the spatial variability of precipitation and its extreme values (Szalińska et al. 2008). Such approved thresholds reflect the variability of precipitation in different periods of a year and the spatial variability of precipitation and their extreme values according to significant diversity of relief and altitude of the Odra River Basin. Days with heavy, very heavy and extreme precipitation may indicate the extent of a hydrological hazard in relation to local conditions and season.

Applying this set of threshold values, the percentage of heavy rainfall in relation to the total rainfall was calculated. This targeted indicator was used to assess the fraction of heavy rainfall during a specified period of time.

A hydrological hazard can be triggered by widespread long-term heavy rainfall. The volumes of such heavy rainfall can reach very high values that sometimes dramatically exceed average monthly totals. For example, in July 1997, in the Nysa Kłodzka River Basin, the 5-day total rainfall (July 5-9) surpassed $400 \mathrm{~mm}$ (Dubicki, Malinowska-Małek 1999). With regard to hydrological

Table 1. Applied precipitation indicators

\begin{tabular}{|c|c|c|}
\hline Indicator & Definition & Unit \\
\hline \multicolumn{3}{|c|}{ A priori indicators } \\
\hline \multirow{4}{*}{ Frequency of severe precipitation events (CZ) } & No. of days with precipitation $\geq 10 \mathrm{~mm}$ (moderately heavy) & \multirow{4}{*}{ day } \\
\hline & No. of days with precipitation $\geq 30 \mathrm{~mm}$ (very heavy precipitation) & \\
\hline & No. of days with precipitation $\geq 50 \mathrm{~mm}$ (hazard precipitation) & \\
\hline & No. of days with precipitation $\geq 70 \mathrm{~mm}$ (flood precipitation) & \\
\hline \multicolumn{3}{|c|}{ Statistical indicators } \\
\hline Maximum precipitation totals $(\mathrm{P})$ & Maximum daily precipitation totals & $\mathrm{mm}$ \\
\hline \multirow{3}{*}{ Frequency of extreme precipitation events (CE) } & No. of days with precipitation $\geq \mathrm{pp}=10 \%$ (heavy precipitation) & \multirow{3}{*}{ day } \\
\hline & No. of days with precipitation $\geq \mathrm{pp}=5 \%$ (very heavy precipitation) & \\
\hline & No. of days with precipitation $\geq \mathrm{pp}=1 \%$ (extreme precipitation) & \\
\hline \multirow{2}{*}{ No. of consecutive wet days (CO) } & Maximum number of consecutive wet days $(\mathrm{P} \geq 0.1 \mathrm{~mm})$ & day \\
\hline & Precipitation total of maximum no of consecutive wet days & $\mathrm{mm}$ \\
\hline
\end{tabular}


hazard assessment, the essential factors are the length of the observed sequences of rainfall and the rainfall totals in these sequences. The assessment of such events is based on the number of consecutive days with precipitation $(\geq 0.1 \mathrm{~mm})$ and also rainfall volume.

Assessment of a hydrological hazard caused by extreme rainfall was based on the analysis of sequence duration and total rainfall values. The threshold values were determined as the values with a $10 \%$ probability of exceedance. This criterion allowed for the distinction of four classes, two of which are important for the assessment of hydrological hazard: Class 1 - short-term extremely heavy rainfall with high intensity, and Class 2 - long-term heavy rainfall with moderate intensity.

\section{The meteorological situation}

At the beginning of May 2010, Poland remained under the influence of low-pressure systems. These conditions allowed for the flow of cool air masses (that had originated over the Northern Atlantic) into Western Europe. Eastern Europe received warm and humid air masses from the Eastern Mediterranean. Thermal characteristics of the air, as well as its humidity and the path of its inflow, confirmed its subtropical origin. Retention of air masses with varying thermal characteristics over Central Europe caused a significant horizontal temperature gradient over Poland. Such conditions prompted heavy precipitation events, which occurred particularly in the south of Poland. The decisive factor influencing the intensity and volume of precipitation

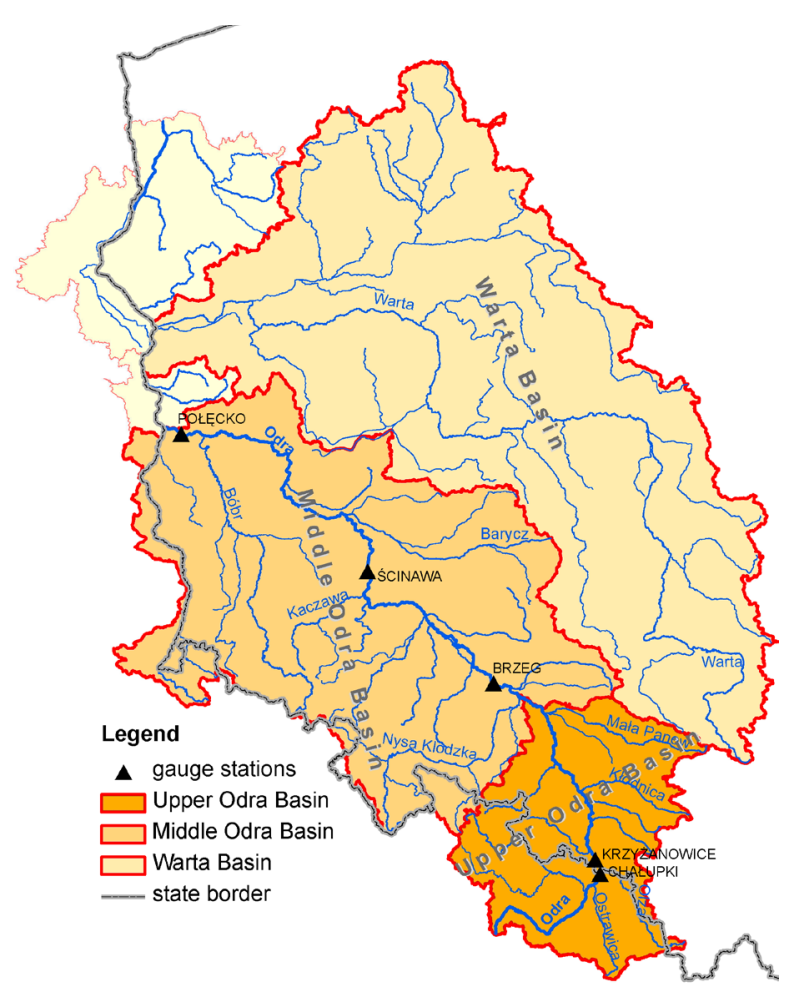

Fig. 2. Spatial distribution of precipitation totals for 14-18 May 2010 in the Odra River Basin; source: Szalińska et al. 2011 was the extremely high humidity of accumulated air masses, as well as a significant thickness of stratus clouds associated with that humidity. The highest continuous precipitation occurred between 15 and 18 May 2010 (Zawiślak et al. 2011)

In contrast, the reason behind heavy precipitation in the south of Poland in the first decade of June 2010 was an expansive low-pressure centre that was vertically welldeveloped. Cyclonic circulation that occurred over Poland brought the highly humid air of subtropical origin into the top layers of the troposphere. This air mass consequently came into contact with a retained mass of humid, though cooler, polar air. The variation of air masses in terms of temperature, humidity and geographical origin promoted the intensification of precipitation. The pressure system forced humid and unstable air masses to move along windward slopes. The highest precipitation occurred between 31 May and 4 June 2010 (Zawiślak et al. 2011).

In the region of the Upper Odra River Basin, spatial distribution of precipitation totals is strongly connected to morphological conditions such as landform and elevation. Therefore, in both meteorological situations, the orographic factor played an important role in the process of developing precipitation intensity.

\section{The highest precipitation total}

Precipitation in the analysed period was of varying intensity. The most intensive precipitation was recorded between 16 and 18 of May, when 3-day totals exceeded $160 \mathrm{~mm}$. They were highest in the Olza River catchment (right bank tributary of the Odra headwaters), with Cieszyn and Istebna Stecówka measuring stations recording $249 \mathrm{~mm}$ and $161 \mathrm{~mm}$ respectively. According to Dubicki (1972), 3-day totals above $160 \mathrm{~mm}$ may be the cause of flooding regardless of hydrological conditions preceding the actual precipitation. The highest 5-day totals occurred between 14 and 18 of May 2010, exceeding $200 \mathrm{~mm}$ in the Upper Odra River Basin (Fig. 2).

The highest daily precipitation ranged from $10 \mathrm{~mm}$ to over $120 \mathrm{~mm}$. The highest values were recorded in the Olza River catchment, with the maximum value of $129.5 \mathrm{~mm}$ recorded on 16 May 2010 at the Cieszyn measuring station (on the Czech border). This was $136 \%$ of the average total for May.

Significantly lower precipitation was recorded in the third decade of May 2010. However, this period was also marked by localised storms featuring heavy rainfall and, in some places, hail. The resulting monthly totals reached maximum values in Cieszyn $(410.4 \mathrm{~mm})$ and Istebna Stecówka $(386.1 \mathrm{~mm})$. The latter was over $120 \mathrm{~mm}$ higher than the previously recorded maximum for May during the 1951-2009 period (Fig. 3).

Precipitation totals for the period between 30 May and 3 June in the Odra River Basin ranged from a few to over $100 \mathrm{~mm}$. Again, the highest totals were recorded in the Upper Odra River Basin. Heavy precipitation, ranging from 


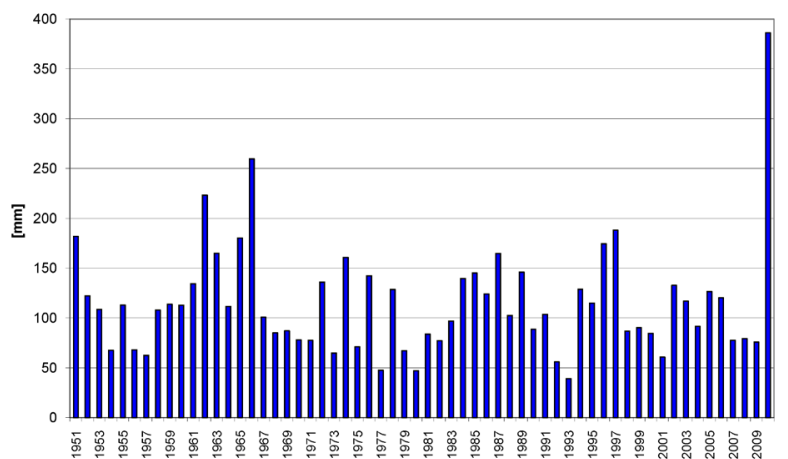

Fig. 3. Monthly precipitation totals [mm] for May at Istebna Stecówka (725 m.a.s.1.) measuring station (Beskid Śląski) during 1951-2010; source: Szalińska et al. 2011

$75 \mathrm{~mm}$ to $100 \mathrm{~mm}$, also occurred in the mountain catchments of the Middle Odra left tributaries.

In the area of the Odra River Basin, during the period May-June 2010, the number of precipitation days (with precipitation $\geq 0.1 \mathrm{~mm}$ ) ranged from 13 to 44 days. In May alone, they ranged from 20 to as many as 30/31days in the south-western part of the Upper and Middle Odra River Basin, i.e. in the catchments of the Mała Panew Stobrawa, Kłodnica, Osobłoga, Olza, Opawa, Nysa Kłodzka rivers, and in the Upper Warta river catchment.

In operational practice of the Polish National Meteorological Services, there are defined thresholds for precipitation values that are applied in a priori assessment of the hazard of flooding for the purpose of issuing warnings. These thresholds rank the daily precipitation totals as: moderately heavy precipitation (exceeding $10 \mathrm{~mm}$ per 24hours), very heavy precipitation (exceeding $30 \mathrm{~mm}$ ), hazard precipitation (exceeding $50 \mathrm{~mm}$ ) and flood precipitation (exceeding $70 \mathrm{~mm}$ ). A warning against flooding is issued when forecasted precipitation exceeds $30 \mathrm{~mm}$, and the highest level of alert is given to precipitation values over $70 \mathrm{~mm}$.

During the analyzed period, one third of all precipitation days featured moderately heavy precipitation. $10 \%$ of the precipitation days were classed as very heavy and occurred in the middle third of May. The highest frequencies of precipitation amounting to $\geq 30 \mathrm{~mm}$ and $\geq 50 \mathrm{~mm}$ in 24 hour periods were observed in the catchment areas of the Olza, Kłodnica and Stobrawa rivers (right bank tributaries of the Upper Odra River), Figure 4. The greatest flood hazard associated with the occurrence of flood precipitation. This precipitation was recorded 11 times, twice at measuring stations located in the Olza River catchment and once at measuring stations located in the Olza, Bystrzyca and Upper Warta catchment areas.

Another indicator providing important information on the hazard of flooding is the length of observed precipitation sequences and their accompanying precipitation totals. The analysis of the longest precipitation sequences $(\geq 0.1 \mathrm{~mm})$ and their totals for May-June 2010 in the Odra River Basin indicated that the number of consecutive precipitation days ranged from 3 to 34 days. The longest pre-

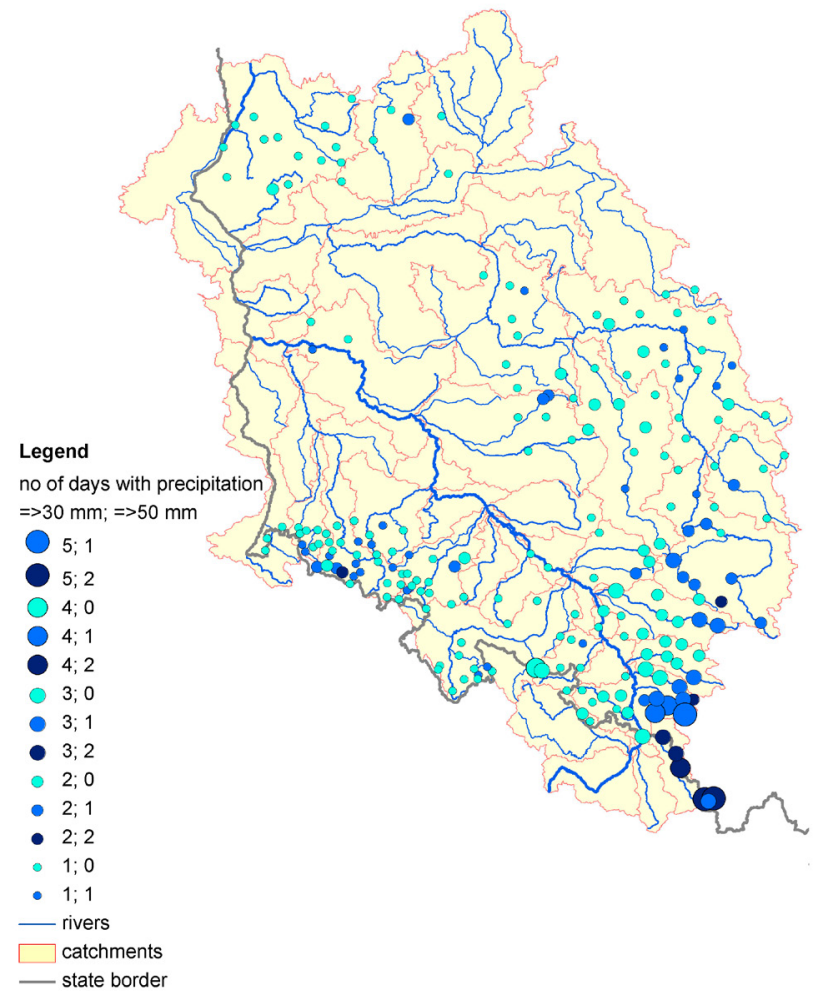

Fig. 4. Daily precipitation totals exceeding $30 \mathrm{~mm}$ and $50 \mathrm{~mm}$ in May-June 2010 in the Odra River Basin; source: Szalińska et al. 2011

cipitation sequence of 34 days was recorded at Głubczyce station (in the Upper Odra River Basin) between 1 May and 3 June 2010, with a precipitation total of $231.5 \mathrm{~mm}$.

\section{Climatological assessment of precipitation}

Climatological evaluation is aims to assess recorded precipitation values in terms of long-term observations. Climatological assessment was carried out for different precipitation characteristics in order to comprehensively investigate the magnitude of the observed precipitation anomalies and indicate extreme events during flooding in the Odra River Basin in May-June 2010. The investigated characteristics included: monthly precipitation totals, daily precipitation totals, intensity, duration and accumulation of precipitation for the number of consecutive wet days. As the reference period for this evaluation the period 1966-2009 was used. Due to the diverse orography of the region, the identification of the observed precipitation events as extreme was made according to indicators that enable the comparison of precipitation levels across different altitudes. Probability of exceedance is one of the most commonly applied climatological indicators of this kind.

Monthly precipitation totals for May 2010 in the Odra River Basin ranged from $70 \mathrm{~mm}$ in its western parts to over $400 \mathrm{~mm}$ in the Olza River catchment (south-eastern part of the basin). The recorded values greatly exceeded the norm based on 1971-2000 data. Extremely high precipitation, exceeding $300 \%$ of the normal monthly totals, occurred in 
the catchments of the right bank tributaries of the Upper Odra River, and also the Upper Warta River catchment.

The adopted statistical indices for the classification of the recorded daily precipitation totals grade the observed values into three categories: heavy precipitation (precipitation with $25 \%$ exceedance probability), very heavy precipitation (10\% exceedance probability) and extreme precipitation ( $5 \%$ exceedance probability). The number and the spatial distribution of days with heavy, very heavy and extreme precipitation show the magnitude of precipitation and risk of flooding. In May-June 2010, the number of days with heavy precipitation ranged from 3 to 18, and those with very heavy precipitation from 1 to 9 days. For 34 stations, very heavy precipitation occurred twice, and for 32 stations it occurred three times (Fig. 5). Recorded extreme precipitation ranged from 1 day (at nearly 60 stations) to as many as 5 days (at the measuring stations in Koźle Port, Baborów, Opole, Sukowice and Stanowice (the Upper Odra River Basin).

The spatial distribution of precipitation days with a set of exceedance probability shows that cases of heavy and very heavy precipitation were recorded in nearly every sub-catchment of the Warta River and the Upper and Middle Odra River Basin. The highest number of days with very heavy precipitation was recorded for the Olza, Kłodnica, Mała Panew, Stobrawa rivers (right bank tributaries of the Upper Odra River).

A comparison of precipitation sequence features for May-June 2010 with equivalent long-term values helps to identify threshold values that define both extremely long

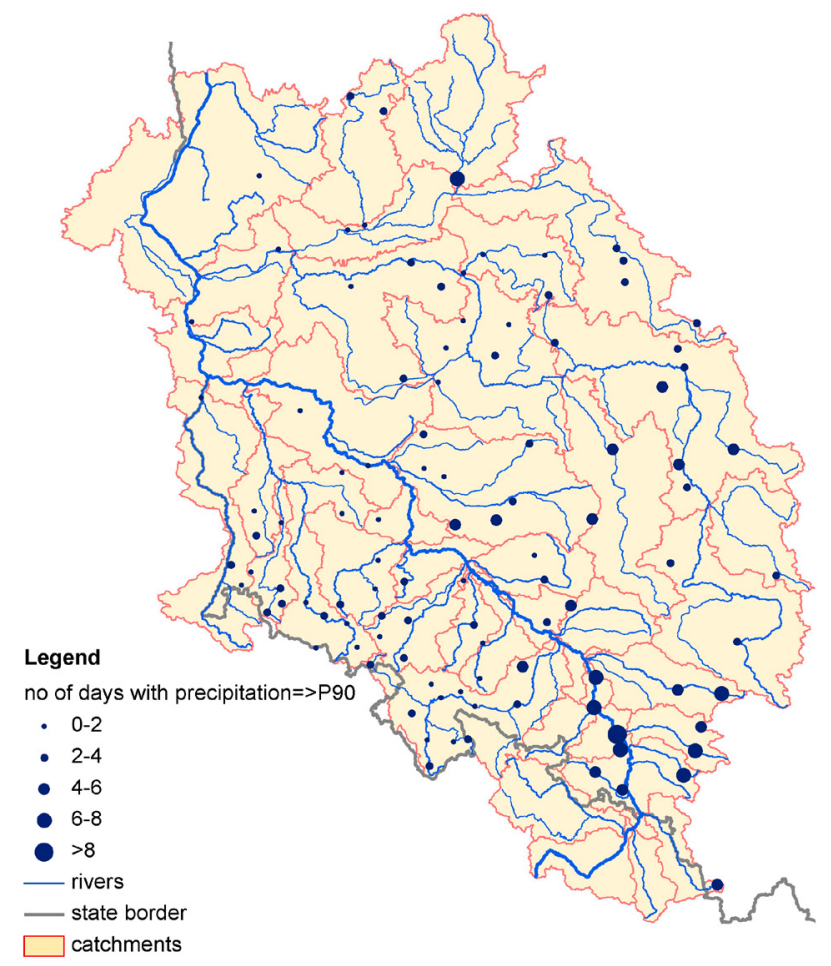

Fig. 5. Occurrences of days with precipitation with $10 \%$ probability of exceedance (very heavy precipitation) in the Odra River Basin in May-June 2010; source: Szalińska et al. 2011 precipitation sequences and extreme precipitation totals within a sequence. For this purpose, it was estimated that for the area of the Odra River Basin, the maximum precipitation sequence did not exceed 10 days and its total did not exceed $70 \mathrm{~mm}$ for $90 \%$ of precipitation events. For the period between 1 May and 30 June 2010, precipitation sequences of the longest duration were categorised into four types by applying these thresholds values. Class 1 and Class 2 denoted precipitation sequences of precipitation totals of maximum $10 \%$ probability of occurrence. Moreover, in the case of Class 2, the number of consecutive precipitation days was higher than $90 \%$ of observed precipitation sequence in the reference period. Class 3 and 4 denoted precipitation sequence totals with values of $90 \%$ probability of occurrence despite the abnormal number of consecutive precipitation days (Class 3 ).

The spatial distribution of the different types of the maximum length and precipitation totals of consecutive precipitation days observed during May-June 2010 is illustrated in Figure 6.

Analysis of these results shows that precipitation sequences that had the features of extreme events (type 2), both in terms of their length and precipitation totals, were recorded at nearly $34 \%$ of measuring stations in the Upper and

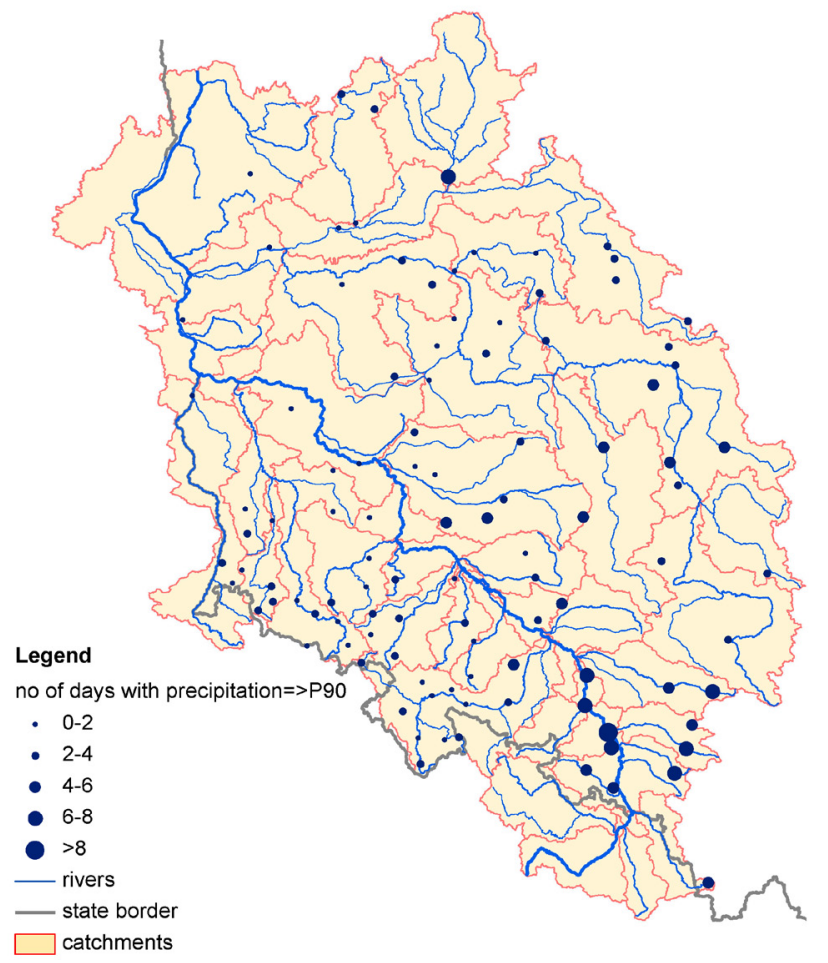

Fig. 6. Spatial distribution of the different types of maximum precipitation sequences: Class 1 - precipitation total exceeding $90 \%$ in the reference period; Class 2 - both precipitation total and the number of consecutive wet days exceed $90 \%$ of observed norm in the reference period; Class 3 - the number of consecutive wet days exceeding $90 \%$ of those observed in the reference period; Class 4 - both precipitation total and the number of consecutive wet days fall into $90 \%$ of observations during the reference period; source: Szalińska et al. 2011 
Middle Odra Basin, and at $25 \%$ of the Warta River catchments. For over $8 \%$ of the stations in the Upper and Middle Odra Basin and $6 \%$ of the stations in the Warta River catchments, precipitation totals in the longest precipitation sequence had features of an extreme event despite the fact that the maximum length of precipitation sequences did not exceed extreme values (type 1). Most cases classed as types 1 and 2 occurred in the catchment areas of the right tributaries of the Upper Odra River and in the Upper Warta River catchments. Precipitation events classed as types 1 and 2 bear most significance in terms of the determining flood hazard.

\section{Flood hazard}

Flood hazard occur in the Odra River Basin almost every year, usually in July and August. The largest flood of unprecedented magnitude, exceeding the most catastrophic assessment, occurred in July 1997, and the second largest was the flood of 1903. The flood of July 1997 was regarded as the Odra's greatest flood of the twentieth century and was a very rare event from the hydrological point of view (Kundzewicz et al. 1999). Table 2 summarises the origins and development of recent severe precipitation floods in the Odra River Basin (Maciejewski et al. 2011).

The flood situation in 2010 had different characteristics, in terms of the location of critical precipitation and the time of occurrence. The critical precipitation affected headwaters of the Odra River, along with the catchments of the right bank tributaries of the Odra River - the Ostravica, Olza and Opawa rivers. High totals of prolonged precipitation covering these areas recorded in May and June 2010 in the Odra River Basin were the reason behind the occurrence of two flood waves. Before the first flood wave (1-13 May), the cumulative precipitation total in the Odra River Basin sub-catchments did not exceed 100 mm (Fig. 7).
The direct cause of the first flood wave was intensive precipitation between 14 and 18 May. In the Mała Panew, Kłodnica and Widawka catchments, the cumulative precipitation total for 1-18 May reached $150-200 \mathrm{~mm}$. In the Olza and Ostravica catchments, the figure exceeded $250 \mathrm{~mm}$ (Fig. 8).

It caused a rapid increase in precipitation water in the Upper Odra and the Upper Warta catchments. Peak values of the water levels were observed during the first wave between 17 and 28 May (Fig. 9).

The next period of extreme precipitation occurred between 30 May and 3 June. This rainfall was responsible for the second flood wave observed along the Odra River between 2 and 10 June. The cumulative precipitation total for the entire two-month period (1 May-30 June) reached over $400 \mathrm{~mm}$ in the Olza catchment. The Olza River catchment was the most affected area during the flood. The increase in precipitation totals for the first period in this catchment reached ca. $100 \mathrm{~mm}$ and, despite a significantly smaller increase in precipitation, the second flood wave was generated mainly by the exceeded catchment retention volume, which caused surface runoff to enter the riverbeds.

Analysis of the collected data indicates that the confluence of the Upper Odra River with the Ostravica and Olza rivers shaped the wave - with a water level $\mathrm{H}=894 \mathrm{~cm}$ and a discharge reaching $1840 \mathrm{~m}^{3} / \mathrm{s}$ at Krzyżanowice gauge on 17 May. This was confirmed by the hydrometric measurement made on 18 May $\left(\mathrm{H}=880 \mathrm{~cm}\right.$ and $\left.\mathrm{Q}=1634 \mathrm{~m}^{3} / \mathrm{s}\right)$. The section of the Upper Odra River to Opole featuring the 4 right tributaries Sumina, Bierawka, Ruda and Kłodnica did not significantly affect the flood. The only left tributary to affect the growth rate of discharge was the Osobłoga River. Flow values in the section from Opole to Wrocław were reduced due to the flooding of 5 polders of total capacity of 25 million $\mathrm{m}^{3}$. The wave subsequently transformed downstream before entering Wrocław Water Junction (junction of the Odra River and 4 active polders of total

Table 2. Characteristics of recent big floods in the Odra River Basin

\begin{tabular}{|c|c|c|c|c|}
\hline & Area of critical precipitation & Affected catchments & Flood situation development & Example of flooding event \\
\hline 1. & $\begin{array}{l}\text { Extended precipitation area over } \\
\text { the mountainous part of the } \\
\text { basin (Beskid Śląski, Oderskie } \\
\text { Mountains, Jesioniki, Bystrzyc- } \\
\text { kie Mountains, Karkonosze } \\
\text { Mountains) }\end{array}$ & $\begin{array}{l}\text { The Upper and Middle Odra } \\
\text { River Basin, catchments of the } \\
\text { left tributaries }\end{array}$ & $\begin{array}{l}\text { Rapid rise of water levels in the } \\
\text { Upper and Middle Odra River } \\
\text { and all its left tributaries }\end{array}$ & 1997 (July) \\
\hline 2. & $\begin{array}{l}\text { Precipitation located over the } \\
\text { area of headwaters of the Odra } \\
\text { River (Oderskie Mountains, } \\
\text { Jesioniki, Beskid Śląski) }\end{array}$ & $\begin{array}{l}\text { The Upper Odra Basin with } \\
\text { Odra headwaters, the Ostravica } \\
\text { catchment, the Olza catchment, } \\
\text { the Opawa catchment }\end{array}$ & $\begin{array}{l}\text { Concentric topology of the river } \\
\text { system in these regions caused } \\
\text { a superposition of the waves be- } \\
\text { tween the Opawa and Ostravica } \\
\text { outlets }\end{array}$ & 1985 (August) \\
\hline 3. & $\begin{array}{l}\text { Precipitation area extended over } \\
\text { the mountainous part of the } \\
\text { Middle Odra River Basin }\end{array}$ & $\begin{array}{l}\text { The Middle Odra catchment, left } \\
\text { tributaries of the Middle Odra } \\
\text { River: the Kaczawa catchment, } \\
\text { the Bóbr catchment, the Nysa } \\
\text { Łużycka catchment }\end{array}$ & $\begin{array}{l}\text { Intensive precipitation over left } \\
\text { tributaries of the Middle Odra } \\
\text { River caused a rapid rise of } \\
\text { water levels }\end{array}$ & 1977 (July/August) \\
\hline
\end{tabular}




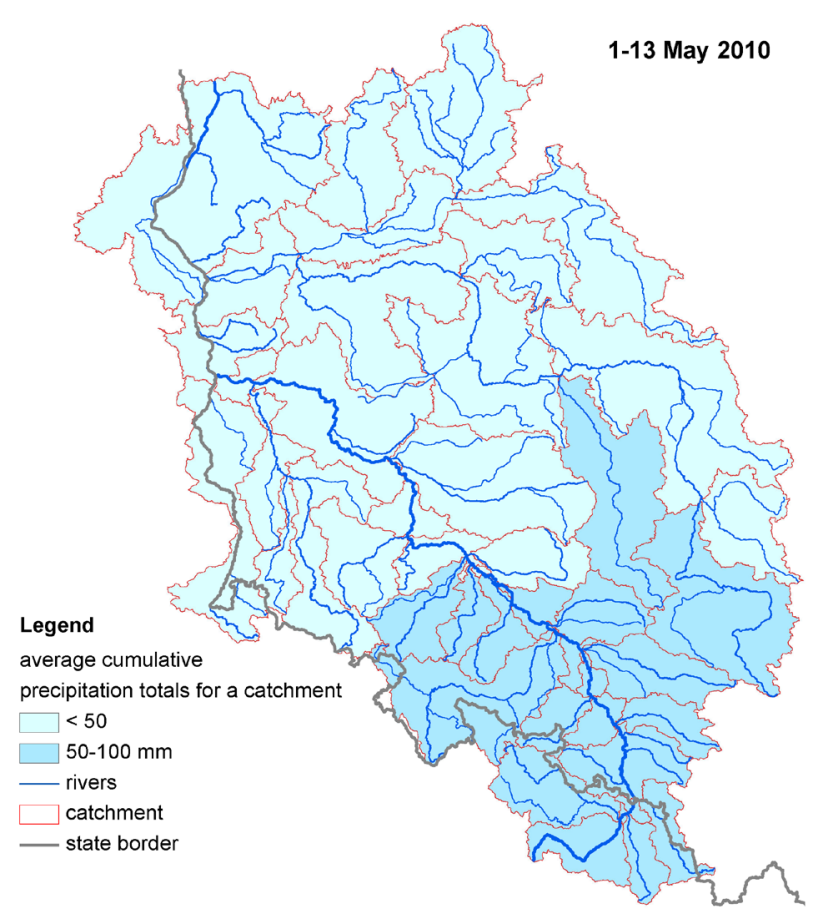

Fig. 7. Spatial distribution of average cumulative precipitation totals in catchment areas before the first flood wave; source: Szalińska et al. 2011

capacity of 50 million $\mathrm{m}^{3}$ ), and the flow reached a value of $1770 \mathrm{~m}^{3} / \mathrm{s}$. In the city of Wrocław, the Odra River is supplied by 4 tributaries. During the 2010 event, these tributaries did not significantly participate in the development of the Odra wave. Discharge increased only to $2070 \mathrm{~m}^{3} / \mathrm{s}$ $(\mathrm{H}=959 \mathrm{~cm})$, as confirmed by the hydrometric measurement $\mathrm{H}=957 \mathrm{~cm}$ and $\mathrm{Q}=1970 \mathrm{~m}^{3} / \mathrm{s}$. After passing Wrocław, high water levels provoked a transfer of water from the Odra River to the Widawa River through the canal. This in turn caused the flooding in the Widawa River outlet. The course of the flood in the Middle Odra River was dominated by the transformation of the flood wave in the main channel and flood plains. The retention of valleys contributed to the successive lowering of the wave down to $1920 \mathrm{~m}^{3} / \mathrm{s}$, and the water level to $805 \mathrm{~cm}$, as confirmed by the measurement $\mathrm{H}=798 \mathrm{~cm}$ and $\mathrm{Q}=1959 \mathrm{~m}^{3} / \mathrm{s}$. In the Middle Odra River section, its left bank tributaries did not

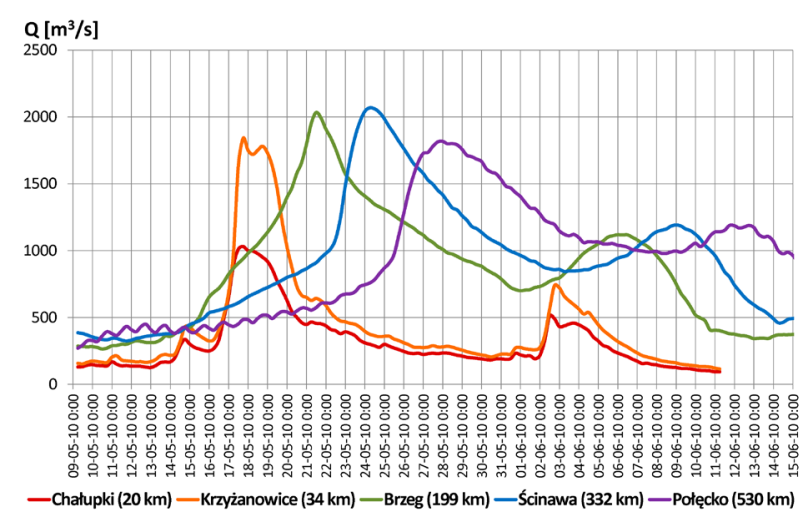

Fig. 9. Water levels on the Odra River, May-June 2010

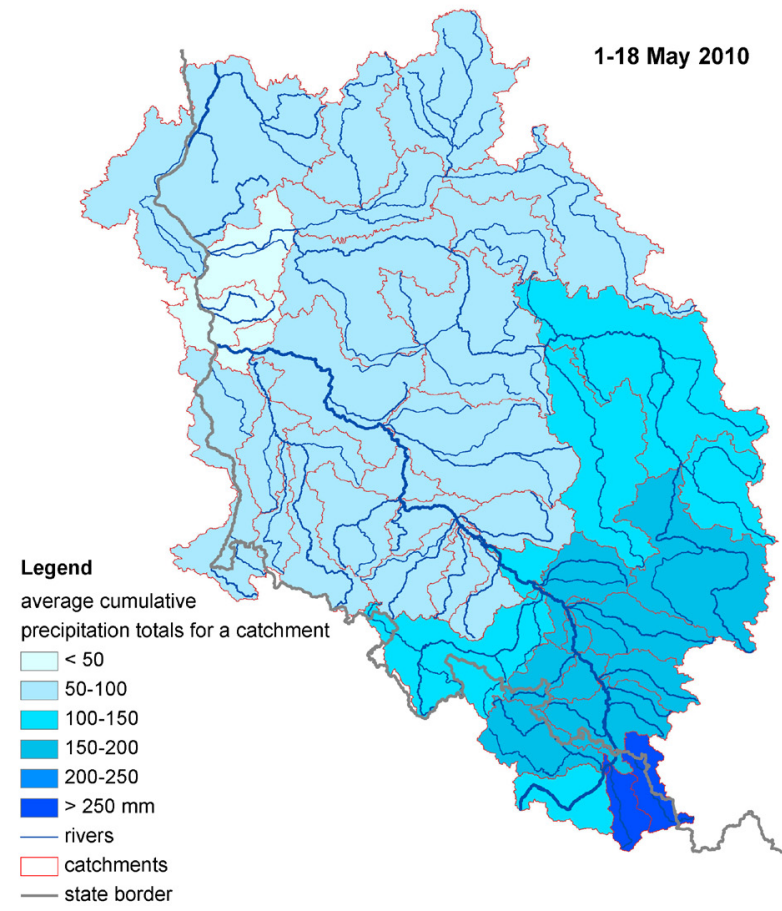

Fig. 8. Spatial distribution of average cumulative precipitation totals in catchment areas during 1-18 May 2010; source: Szalińska et al. 2011

significantly impact on the development of the wave. The discharge of the Odra River was increased only by the waters from right bank tributaries, particularly from the Warta River. Downstream from the mouth of the Warta River, the flow exceeded $2200 \mathrm{~m}^{3} / \mathrm{s}$ and caused flooding of the surrounding areas.

Comparison of the 2010 event with the recent historical floods proves that although water levels corresponded to those observed in 1997, the flow values were much lower. In 2010, the wave propagated through the main channel and flood plains, and there were no significant interruptions of embankments. Figure 10 shows the size of the 2010 flood and the variability of flood flows in the longitudinal profile of the Odra (red line) superimposed on the figures developed for selected historical flood events. The

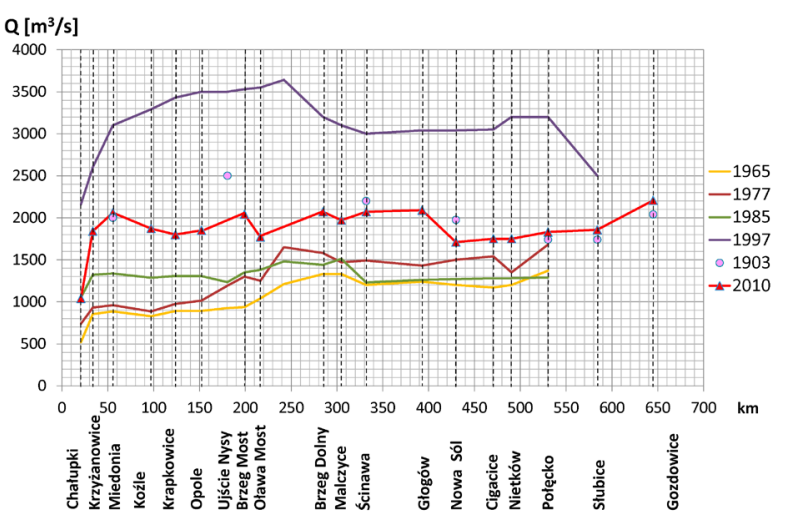

Fig. 10. Variability of flood flows in the longitudinal profile of the Odra River for selected flood events in the 20th and 21 st centuries 
flood in 2010 was similar to the estimated flows in 1903 in terms of volume discharge.

Smaller values of flows along the Odra River caused many fewer fatalities in 2010 than in 1997. Still, damage caused by flooding in the Odra River Basin affected 7 voivodeships in Poland. The farming industry was badly affected, as agricultural areas (both farmlands and green areas), farms and processing plants were flooded. The flooding also affected transport and municipal infrastructure, as well as large parts of protected areas in river valleys.

\section{Concluding remarks}

Assessment of the flood hazard caused by precipitation involves analysis of the precipitation amount, duration and spatial extent. The developed set of precipitation indicators was applied to evaluate and identify precipitation extremes with regard to the precipitation magnitude, location and time of occurrence. The set included $a$ priori indicators and statistical indicators. The first category provides prompt insight into hazard levels and has application in operational work, notably in the issuing of warnings. Statistical indicators are based on the climatological assessment of the observed long-term datasets. They enable the reproduction of seasonal and spatial variability of precipitation characteristics. Indicator values were categorized in order to determine flood hazard levels and evaluated in the catchment scale. The results obtained for the Odra River Basin in May-June 2010 show that the catchments with recognized high levels of flood hazard were affected by the flood wave. Unlike the typical summer flood scenario in the Odra River Basin, in 2010 intensive precipitation was observed as early as in May. Also, the location of the most intensive rainfall shifted to the catchments of the right tributaries of the Odra River, where, in May 2010, the highest precipitation values since 1951 were recorded.

Against the background of the five largest flood events of the last century, the flood in 2010 proves that the water levels corresponded to those observed in 1997. However, the flow values were much lower and corresponded to the estimated values for the flood of 1903. For the majority of locations, the flood wave, caused by the observed extreme precipitation, propagated through the main channel and flood plains, inducing relatively small flood damage.

Developed set of indicators can be applied for real-time flood prediction and control in order to estimate flood hazard level on the given area based on the precipitation forecasts obtained from weather prediction models.

\section{Bibliography}

Bissolli P., Friedrich K., Rapp J., Ziese M., 2011, Flooding in eastern central Europe in May 2010 - reasons, evolution and climatological assessment, Weather, 66 (6), 147-153, DOI: 10.1002/wea.759
Dubicki A., 1972, Przebieg wezbrania w lipcu 1970 r. w dorzeczu Odry (July 1970 flood in the Odra River Basin), [in:] Powódź w lipcu 1970 r.: monografia, S. Ihnatowicz, K. Fiedler, A. Stolarska (eds.), WKiŁ, Warszawa, 100-112

Dubicki A., Malinowska-Małek A., 1999: Wysokość, natężenie i przestrzenny rozkład opadów atmosferycznych (High, intensity and spatial distribution of atmospheric precipitation), [in:] Dorzecze Odry. Monografia powodzi. Lipiec 1997, A. Dubicki, H. Słota, J. Zieliński (eds.), IMGW Warszawa, 23-44

Dubicki A., Malinowska-Małek J., Strońska K., 2005, Flood hazards in the upper and middle Odra River basin - A short review over the last century, Limnologica, 35 (3), 123-131, DOI: 10.1016/j.limno.2005.05.002

Maciejewski M., Ostojski M., Tokarczyk T. (eds.), 2011, Dorzecze Odry monografia powodzi 2010 (The Odra River Basin 2010 Flood Monograph), IMGW-PIB, Warszawa, 164 pp

Klein Tank A., Zwiers F., Zhang X., 2009, Guidelines on analysis of extreme in a changing climate in support of informed decisions for adaptation, Climate Data and Monitoring WCDMPNo. 72, WMO-TD No. 1500, 56 pp

Kundzewicz Z., Szamałek K., Kowalczak P., 1999, The Great Flood of 1997 in Poland, Hydrological Sciences, 44 (6), 855870

Moberg A., Jones P.D., 2005, Trends in indices for extremes in daily temperature and precipitation in Central and Western Europe, International Journal of Climatology, 25 (9), 11491171, DOI: 10.1002 joc. 1163

Nicholls N., Murray W., 1999, Workshop on indices and indicators for climate extremes: Asheville, NC, USA, 3-6 June 1997. Breakout Group B: Precipitation, Climatic Change, 42, 23-29

Sen A.K., Niedzielski T, 2010, Statistical Characteristics of Riverflow Variability in the Odra River Basin, Southwestern Poland, Polish Journal of Environmental Studies, 19 (2), 387-397

Szalińska W., Urban G., Otop I., 2008, Próba oszacowania wysokości opadów wywołujących wezbrania letnie w dorzeczu Środkowej Odry (Assessment of precipitation volumes causing summer floods in the Middle Odra River Basin), Infrastruktura i Ekologia Terenów Wiejskich, 9, 227-238

Szalińska W., Otop I., Farat R., 2011, Struktura czasowoprzestrzenna opadów atmosferycznych w dorzeczu Odry, [in:] Dorzecze Odry monografia powodzi 2010 (The Odra River Basin - 2010 Flood Monograph), M. Maciejewski, M. Ostojski, T. Tokarczyk (eds.), IMGW-PIB, Warszawa, 32-47

Wrona B., 2008, Meteorologiczne i morfologiczne uwarunkowania ekstremalnych opadów atmosferycznych w dorzeczu górnej i środkowej Odry (Meteorological and morphological conditions of extreme precipitation in the Upper and Middle Odra River Basin), Materiały badawcze IMGW, Meteorologia 41, Warszawa, 120 pp.

Zawiślak T., Adamczyk Z., Bąkowski R., 2011, Synoptyczne uwarunkowania powodzi, [in:] Dorzecze Odry monografia po-wodzi 2010 (The Odra River Basin - 2010 Flood Monograph), M. Maciejewski, M. Ostojski, T. Tokarczyk (eds.), IMGW-PIB, Warszawa, 17-31 